\title{
Political Opportunity and the Rise and Decline of Interest Group Sectors
}

\author{
DAVID S. MEYER* \\ University of Michigan \\ DOUGLAS R. IMIG \\ University of Nevada, Las Vegas
}

\begin{abstract}
Interest group activity is always affected by the political environment in which groups operate. As a result, effective study of public interest groups must situate them in a larger political context. We propose a means of doing so by building on theoretical and empirical studies of both social movements and interest groups. We argue that groups can best be understood by changing the unit of analysis from an individual group to the set of groups pursuing common agendas, or an "interest group sector." Drawing from both empirical and theoretical literature, we establish both the necessity and the theoretical parameters for a sectoral analysis, and offer a basic framework for such an analysis. We demonstrate empirical support for a sectoral approach by looking at the periodicity of group formation in five public interest sectors. We then propose a six stage framework to describe a cyclic process of issue emergence, resource mobilization, organization building, and their relation to the policy process. We conclude by discussing the potential policy impact of interest group mobilization and institutionalization, and its relationship to democracy.
\end{abstract}

Interest groups make history, we might paraphrase an earlier analyst, but not in circumstances they choose. Instead, they are aided, encouraged, and/or thwarted in their efforts by a number of structural and strategic factors that shape their emergence, development, and demise. It is only by recognizing the contextual constraints on interest group activity that we can begin to understand their successes and failures, the utility and costs of various strategies, and most significantly, the

*Direct all correspondence to: David S. Meyer, Political Science, 5602 Haven Hall, University of Michigan, Ann Arbor, Michigan 48109 (313) 764-6312.

The Social Science Journal, Volume 30, Number 3, pages 253-270.

Copyright ${ }^{\circledR} 1993$ by JAI Press Inc.

All rights of reproduction in any form reserved. ISSN: 0362-3319. 
role of organized groups in the larger policy process. Effective study of interest groups must situate the groups in a larger political context. We suggest a means of doing so by building on theoretical and empirical studies of both social movements and interest groups. In this article we argue that interest group politics can best be understood by changing the unit of analysis from an individual group to a larger collection of groups with similar concerns, or an interest group sector. This approach allows the analysis of groups and their political influence to be more closely integrated with the broader social and political phenomena and the larger policy process of which they are a part.

We begin by briefly reviewing the literature on the origins of interest groups and their relation to a larger political context, explaining why a new approach that addresses sectors rather than individual groups is needed. We then discuss the important role that external factors have on potential social mobilization and organization building, using literature on political opportunity and policy reform. Having established both the necessity and the theoretical parameters for a sectoral analysis, we offer a basic framework for further study. We demonstrate empirical support for a sectoral approach to the study of interest groups by looking at patterns of group formation in six public interest sectors. Building on a variety of empirical and theoretical studies, we propose a five stage framework to describe the process of organization building and its relation to the policy process. We conclude by discussing the potential policy impact of mobilization and institutionalization.

\section{INTEREST GROUP ORIGINS AND POLITICAL CONTEXT}

Students of interest groups, mostly working in political science, and students of social movements, mostly in sociology, have worked on parallel tracks for several decades, first overstating, then undervaluing, the effect of political context on political mobilization and representation. Unfortunately scholars in the different disciplines have generally talked past each other, rarely drawing from each other's work. The process of mobilization in social movements is, however, clearly related to the organization of interest groups, and both are affected by and influence the larger political climate.

Truman gave voice to the post-war pluralist notion that interest group participation in the political process is an inherent characteristic of the American system; he traced the origins of groups to the external political environment. Disturbances in society, in particular new political issues or constitucnts, give risc to a "spontaneous coalescence of interests" in the form of groups that compete for access and influence in American politics. ${ }^{1}$ Dahl developed and formalized the pluralist paradigm with his notion of "polyarchal democracy," in which groups develop to represent nascent constituencies, then bargain with political leaders and parties for influence on the policy process. Acknowledging the unequal distribution of resources among groups, Dahl nonetheless contended that no nascent group was without resources, or the potential to develop solidarity and influence within the political arena. ${ }^{2}$

Dahl's early version of pluralism has endured an unrelenting series of attacks from numerous perspectives. A wide range of analysts argued that some groups 
are denied access not only to the political arena and to organizational resources, ${ }^{3}$ but even to the political consciousness needed to frame demands. ${ }^{4}$ Others questioned whether the political product of conflicting groups is just, in the national interest, or even a contribution to effective governance. ${ }^{5}$ Critics of pluralism raise three sets of questions, first: which groups are able and likely to mobilize and in what venues? Second, to what extent is this mobilization the result of circumstances within a group's control? Third, what is the relationship between groups, once organized and institutionalized, to their purported constituency and its interests, and to public policy?

Truman's analysis of groups, explicitly political, focused analytic attention on the conditions or disturbances which gave rise to their emergence. The development of any group reflected the larger political environment, a reasonable premise. The essential flaw, however, is the supposition that group representation is a transparent reflection of the constellation of diverse interests in society, the assumption that any "disturbance" would create group representation, and conversely, that any group was the result of a political disturbance. Paradoxically, this tautology diminishes the analytic importance of tactical choice, the stuff of politics.

The next wave of scholarly attention focused on the difficulties inherent in mobilizing political activity and sustaining organizations. Olson and subsequent observers focused instead on the organizational dynamics of groups, criticizing the pluralist paradigm for overvaluing the contribution of political programs to group formation and maintenance. ${ }^{6}$ Olson contends potential groups members are likely to "free ride" on group activity, recognizing that their marginal contribution to group activity seldom affects a group's political prospects, yet carries personal costs. Groups can overcome this problem by offering selective incentives to prospective members in return for participation. By focusing on "exchange" relationships, ${ }^{7}$ the rational actor model drew needed attention to the internal workings of groups, but in the process political activity became little more than a means to attract supporters and provide for organizational maintenance. Clearly, however, external political circumstances set the context in which the calculus of participation takes place, determining the urgency of particular issues, and the scope and intensity of conflict. ${ }^{8}$ The critical problem remains integrating the internal processes of groups with their larger political role.

The literature on social movements developed along a parallel path. In the 1950s and $1960 \mathrm{~s}$, analysts generally attributed the emergence of social protest movements to some kind of societal dysfunction. Social protest, a form of expression seen as entirely distinct from conventional interest group participation, was the product of some kind of social breakdown, a function of anomie, society's failure to provide "intermediary associations," "relative deprivation," or some other kind of aggregate psychological disorder. ${ }^{9}$

Responding to the political movements of the 1960s, which the old "break-down" approaches could neither explain nor analyze effectively, scholars began to view social protest as a political choice made by those unlikely to win through more conventional political activities. Like students of interest groups, social movement scholars turned to the exchange relationships through which organizers produced protests. The "resource mobilization" model stressed the rationality of protest 
politics and the role of organized groups in structuring social movements. ${ }^{10}$ Often, however, the political context, and particularly the role of the state, disappeared in this model. Recent literature on protest has reintegrated the role of political context and state action in shaping social protest movements by recognizing that changes in context alter the marginal values of resources and incentives in exchange relationships. ${ }^{11}$

Political context is especially significant to public interest representation. While Olson's free rider seems to void possibilities for the emergence of groups explicitly concerned with collective goods, or representing constituencies with extremely limited political resources, the free rider problem is clearly not insurmountable, as public interest groups $d o$ form, survive, and advocate for policy change. ${ }^{12}$ Indeed, members of such groups derive satisfaction from participating, often even in the absence of selective benefits. This suggests that some number of individuals are willing to make personal sacrifices in order to participate in public interest advocacy, or that they may indeed view political participation not as a cost, but as a benefit in itself. ${ }^{13}$ The circumstances under which large numbers of people are willing to take this view, however, are limited, both in occurrence and duration. We need to look critically at context in order to understand just what these conditions are.

We see the free rider problem as less a constant obstacle than an elastic tendency that responds to external circumstances. It is not surprising, for example, that contributions to a good government group such as Common Cause increased in the wake of the Watergate scandal, or that membership in environmental groups increased in response to Reagan administration policy and rhetoric environmentalists found provocative, or that a movement against nuclear weapons flourished during the early Reagan years, when the President spoke of "winnable" nuclear wars and engendered elite, as well as mass, opposition. ${ }^{14}$ In times of perceived crisis, free riders are less likely to see non-participation as rational or justifiable; in times of large scale mobilization, they are more likely to see their participation as potentially efficacious, creating a sort of pile-on or bandwagon effect. ${ }^{15}$

\section{CONTEXT AND MOBILIZATION: POLITICAL OPPORTUNITY STRUCTURE AND DISSIDENT MOVEMENTS}

Political context and institutional structures shape the opportunities for dissent and channel its expression. Systematic integration of context in the analysis of social protest and interest representation has developed slowly within the social science literature. Eisinger used the "structure of political opportunities" as a set of independent variables to explain which urban governments were most likely to encounter protest in the late $1960 \mathrm{~s} .{ }^{16} \mathrm{He}$ found protest most likely to occur in cities with a combination of what he termed "open" and "closed" institutions, that is, moderately accessible to citizen claims and participation. A complete lack of tolerance for dissent deterred protest while extremely open and accessible governments preempted it. In short, the availability of institutional means of redress dircetly affected the mobilization of dissent and the tactical choices activists made.

Tilly applied Eisinger's findings to national governments, emphasizing the continuity between extra-institutional and institutional political action, and the 
state's role in channeling dissent. States can repress protest, or channel it into less volatile or disruptive venues. In this way repressive states can postpone or prevent the emergence of social protest, while extremely tolerant states may preempt protest by bringing new challengers into the polity. ${ }^{17}$ Seemingly like movements meet very different fates depending on the political institutions they challenge. Governments control both the degree of access to decision-making groups enjoy as well as their own policy responses. In a cross-national comparison of antinuclear power movements in four liberal polities, Kitschelt explained both movement forms and policy influence with reference to formal state structures. Antinuclear activists confronting relatively closed states, such as France, chose confrontational strategies, he contends, while their counterparts in more open and less efficacious states, like the United States, chose "assimilative" approaches. ${ }^{18}$

The approaches outlined above look at opportunity structures as constants, useful analytically only for cross-sectional comparisons, but opportunity is not simply a function of relatively static institutions. ${ }^{19}$ Policy and policymakers also play critical roles and change over time. McAdam advances a political process framework, in which there is an interplay between state action and insurgent challenges. He shows, for example, that a decline in the number of lynchings in the 1930s provided blacks in the United States with sufficient space to begin building stronger indigenous political organizations. ${ }^{20}$ In response to the emergence of a growing and potentially disruptive civil rights movement in the 1960 s, President Kennedy, along with funders and other political figures, worked to funnel dissident activities into less disruptive channels, including voter education and registration. ${ }^{21}$ The availability of additional venues for political action, particularly within urban politics and the Democratic party, thus split the civil rights movement into two camps, one committed to working within political institutions for incremental gains, another committed to extra-institutional protest and advancing broader claims.

This example suggests not only that incipient groups must have some degree of political freedom in order to mobilize, but also that they will strive to differentiate between themselves, entrench their organizations, and secure resources in response to a changing political environment. Researchers identify similar patterns of public interest group constraint by, and response to political context over time in women's liberation, farm workers, antinuclear weapons, and poor pcople's movements. ${ }^{22}$

\section{OPEN MOMENTS, POLITICAL SPACE, AND POLICY WINDOWS}

Both institutional activity and system-level crisis can create opportunities for mobilization within a sector. Political crises can open the political system to new challenges and alternative policies, creating what Gourevitch terms "open moments." 23 State failure can politicize the citizenry and fragment elite unity, potentially prompting reexamination of both government policy and political alliances. As new political alignments emerge, the balance of power between the contenders may be fundamentally altered, creating new openings in the structure of political opportunity. Organized labor, for example, enjoyed substantially more institutional political influence in the New Deal coalition than it did in the political alignments following the crises of the $1890 \mathrm{~s}$ and $1970 \mathrm{~s}^{24}$ 
Major realigning crises are rare, however, while social protest and interest group mobilization are not. Policy reform or public events can also enhance the "political space" available to public interest groups, that is the "opportunities for legitimate mobilization not monopolized by established linkage mechanisms." 25 Political space expands as new policy problems appear, as government policy changes, and as political expectations are raised. It contracts as activist concerns are satisfied or as public attention shifts away from a sector's concerns. Interest groups, along with government institutions, political parties, and other groups, attempt to take advantage of expanding political opportunity, and compete for survival as these opportunities diminish. ${ }^{26}$ As windows of opportunity close, a new institutional order develops with a new policy consensus that inhibits the development of new challenging organizations and limits the available space on the political agenda for new claims. ${ }^{27}$

\section{TOWARD A SECTORAL ANALYSIS}

Several generations of research on interest groups and social protest movements has yet to produce anything approaching consensus on their role in the policy process. In part, this reflects the fluid nature of American politics and the difficulty of assessing meaningful access to policy makers and political influence. Further complicating the issue, groups rarely act alone in or around the policy process. Numerous groups generally work in coalition and competition on given policy areas, applying a broad range of tactics to sometimes similar and sometimes different ends. As a result, identifying discrete causes for a group's success or failure is no simple matter. By moving to consider the broader set of actors concerned with a particular policy area, we can develop a stronger approach to evaluate group influence on the policy process.

A great deal of research and theory has been directed at particular aspects of the relationship between movements, groups, and their environments, focusing, for example, on the activity and development of single group, ${ }^{28}$ comparing tactics across a number of different groups; investigating internal group dynamics, characterizing group decision-making and survival, and discussing the overall shape of pressure politics in America. ${ }^{29}$ Considering sectors, rather than individual groups, allows us to bridge the gaps between studies of particular groups and macropolitical analyses.

Rescarch on "issuc networks" in political science, and on "policy domains" in sociology, has begun to build these bridges. ${ }^{30}$ Focusing narrowly on the policy process, such network analyses recognize the important roles of such diverse actors as legislative staff, agency administrators, academic experts, foundations, and a host of interest group lobbyists. These analyses neglect, however, the broader political context in which networks exist. A sectoral approach remedies this deficit.

Interest group sectors are composed of the set of organized groups that share broadly similar policy concerns. ${ }^{31}$ Their shared political concerns encourage groups both to form alliances to enhance policy influence, and to compete in pursuit of resources such as members, patrons, issues, causes, and privileged access to government. ${ }^{32}$ Sectors reflect to some degree the variety of private interests 
operating in American politics, replicating the interests, for example, of various industries, regions, or constituencies. We are most concerned with those sectors explicitly concerned with public interest causes. Set against the variety of groups representing private interests operating in American politics, public interest groups maintain only a tenuous hold on organizational resources and policy access.

By definition, public interest groups pursue political benefits not limited to members of the group, for example: clean air, diminished threat from nuclear weapons, comprehensive labelling on processed food, or the eradication of poverty. ${ }^{33}$ Because public interest groups are highly vulnerable to shifts in both public concern and governmental response, they are a sensitive bellwether of the representative dynamic at work in the United States. ${ }^{34}$ The extent to which they reflect, amplify, or minimize public concerns is thus an important measure of democracy.

Placing the interest group sector at the center of analysis allows an awareness of the systemic variables that cause issues to move in and out of public attention, and these factors must inform detailed examination of individual groups. Sectoral analysis allows for both an evaluation of the marketplace as a whole, and a comparison of tactics adopted by groups within the same sector, ostensibly facing the same conditions and pressures. We can assess the utility of group choices by comparing the success and survival of groups within the same sector. We can examine the effects of contextual factors by studying the growth or decline of the sector as a whole.

Analysts of interest groups have already worked within the basic precepts of sectoral analysis, identifying, for example, the differing concerns, tactics, and resources of labor, corporate, and ideologically-oriented groups. ${ }^{35}$ In defining public interest group sectors, analysts tend to assume a coincidence of interests and constituents, as in business and labor organizations. ${ }^{36}$ This approach relegates public interest groups to an undifferentiated "other" category. It also operates under the assumption that groups expressing diverse concerns such as women's rights, human rights, environmental protection, opposition to war, and various visions of social justice will operate in the same way as groups that define their interests far more narrowly. A constituency definition is inadequate within public interest sectors, first because most groups explicitly disdain the notion that they represent a particular segment of society, and second, because virtually all public interest groups generally appeal for support directly to the same broad constituency, primarily the well-educated middle classes and a relatively small group of private foundations and governmental funders.

Sectors are better characterized by the political ends groups seek, even if political goals may shift in response to organizers' perceptions of the political opportunities they face. This means that groups may move from issue to issue, or even straddle sectors in response to the political environment. ${ }^{37}$ Groups define their concerns with one eye toward their constituents and potential constituents, and another toward the political arena. Thus leaders are concerned not only with the most pressing issues, but also with the specific concerns of their members and sponsors. Group entrepreneurs are exceptionally sensitive to fluctuations in the market because they have to be. 


\section{MOBILIZATION AND COMPETITION WITHIN PUBLIC INTEREST SECTORS}

Public interest movements are able to generate only sporadic peaks of mobilization, but not for want of trying. Indeed, activists are always trying to achieve their vision of the public interest by mobilizing action to influence government. This constancy of effort, in conjunction with only occasional bursts of mobilization, suggests that we should look beyond the internal dynamics of a group to understand its successes and failures.

Political organizations depend on the flow of resources, including money, members, and attention. Yet potential funders seeking policy influence often prefer other avenues of access. If funders have more direct routes of political influence, supporting the less direct route of interest group activity becomes less attractive. Further, while professional and managerial associations rationally cooperate to pursue economic self-interest, these same associations have every incentive to freeride on public interest advocacy. This dynamic limits the types of groups and political causes foundations, corporations and private individuals are likely to support.

In pursuit of organizational survival, groups seek stable supplies of resources. To this end they attempt to establish "domain" over clients, members, functions and services. ${ }^{38}$ In times of sectoral expansion, organizations proliferate, each seeking to capture resources available to the entire sector. ${ }^{39}$ New organizations spring up and old ones orient themselves to popular new issues. Common Cause, for example, expanded its traditional good government agenda to include nuclear weapons issues in the early 1980s, when public attention to defense issues increased in the wake of a broad challenging movement on nuclear weapons policy. Although not clearly linked to the Common Cause charter, leaders believed, correctly as it turned out, that such a shift would aid the organization's growth. ${ }^{40}$

At a movement's peak, we see a familiar pattern in which a broad and diverse coalition of groups loosely unites in the pursuit of a few broadly defined goals. Civil rights, for example, unified a diverse insurgent movement in the 1950s and 1960s. Shortly afterward, an extremely diverse coalition smerged to oppose the Vietnam war. The breadth of a movement coalition, and the number of constituent groups within it, affect the form and potential influence of mobilization. A broad and decentralized coalition widens the range of potential entry points to political activism. Movement coalitions then may aim at a variety of access points, becoming far less predictable and less susceptible to repression or cooptation.

Individual groups are often overshadowed, however, by the larger movement. When available resources are expanding, each group can carve out an independent niche and capture distinct issues and constituencies. The environmental protection sector, for example, includes groups primarily concerned with preserving public lands and others focused on preventing toxic waste dumping. Diversity and growth within a sector is a strength for policy influence, but it may be problematic for individual groups. ${ }^{41}$ As a sector saturates, either through group proliferation or through diminished resources, groups increasingly come into competition with each other, needing a larger market share in order to maintain themselves. The imperative 
of organizational survival virtually forces allied groups to distinguish themselves not only from each other, but from the movement as a whole. Consequently, as a movement grows and draws more organizations into its wake, each organization is subjected to increasingly powerful pressures to specialize, breaking away from a larger coalition in the process. ${ }^{42}$

Internal pressures to institutionalize and centralize decision-making lead to the development of bureaucratic structures more suited to organizational survival than either tactical innovation or political influence. ${ }^{43}$ Even coalitions face these pressures as they come to compete for resources available to the whole sector. The nuclear disarmament movement's history illustrates this process. Activists formed the Committee for a Sane Nuclear Policy (SANE) in 1957 to coordinate a broad spectrum of peace activism. SANE quickly became a distinct and independent organization, as did Mobilization for Survival in 1970s, and the Nuclear Weapons Freeze Clearinghouse in the 1980s. In each case the coalition became a distinct organizational entity, with its own staff, direction, and survival pressures. ${ }^{44}$ Coordinating groups effectively created additional competition within the sector in the form of a new professional organization.

This course of professionalization and bureaucratization of movement organizations is endemic to social movements in the United States, and it is also problematic. Institutionalization and professionalization redirect many groups toward more modest, and inherently more conservative, objectives. As Wilson notes, "In the long run ... all organizations seek some form of accommodation with their environment, because the costs of sustaining indefinitely a combatoriented organization are generally too high to be borne by the members." 45

Wilson, valuing systemic stability, sees this accommodation and moderation as a virtue of pluralist politics. Piven and Cloward concur with his analysis of organizational evolution, but challenge his normative evaluation, contending that institutional politics fails to respond to challenging groups unless threatened by disruption. They argue that challengers can enhance their prospects for influence by emphasizing disruptive mobilization rather than organization building. ${ }^{46}$ The leading edge of mobilization almost invariably comes from outside established organizations, as institutional groups develop a patterned form of expression and activism that is insulated from new constituencies, concerns, and tactics. ${ }^{47}$

As sectors contract, entrenched groups choose tactics to ensure their survival by improving prospects for financial support and legislative access. Strategies for hard times include neutering their political agenda and concurrently distancing themselves from grassroots constituents in order to moderate goals and tactics. Conventional political action in pursuit of moderate goals may generate incremental victories in institutional politics, but it seldom motivates grassroots activism. Paradoxically, as a group or coalition moves closer to the Washington culture, it becomes less threatening as it sheds its grassroots movement ties. As the distance between the movement and its institutional representatives increases, both wings suffer. Groups in Washington lose their "left," with its movement-based legitimacy and disruptive potential. The grassroots lose media attention, ${ }^{48}$ an organizational base, and the capacity to mobilize. Organizations generally survive at the expense of the movements that create them. ${ }^{49}$ 


\section{POLITICAL OPPORTUNITY AND SECTORAL EXPANSION: A PRELIMINARY TEST}

We have argued that public interest group formation and survival reflects the external political environment. During periods of expanding political opportunity in a sector, new groups form and existing groups tlourish. Conversely, as opportunity within a sector constricts, the number and well-being of groups in that sector should also suffer. If this is true, we should be able to observe the phenomenon in the development of various sectors. Using national organization directories, ${ }^{50}$ we compiled founding dates between 1900 and 1985 for groups within five different public interest group sectors: anti-poverty, civil rights, animal rights, child welfare, and consumer protection. For each sector, we included all groups with primarily national rather than regional interests and which indicated a principal concern with national advocacy or legislative activity rather than service provision. We condensed multiple organizations that shared addresses, phone numbers, and boards of directors to one listing, yielding a sample of 196 groups.

Founding dates reflect sectoral mobilization, as groups form during periods of sectoral expansion. Since entreprenuerial skill is likely to be distributed randomly across sectors and over time, if this were the most important variable affecting group formation, we would expect to find a random distribution of group formation dates. Instead, the rate of group formation as a whole varied dramatically, as this tactic of political representation was advantaged at certain times. Rather than appear with equal likelihood across each of the years under investigation, we find an upsurge

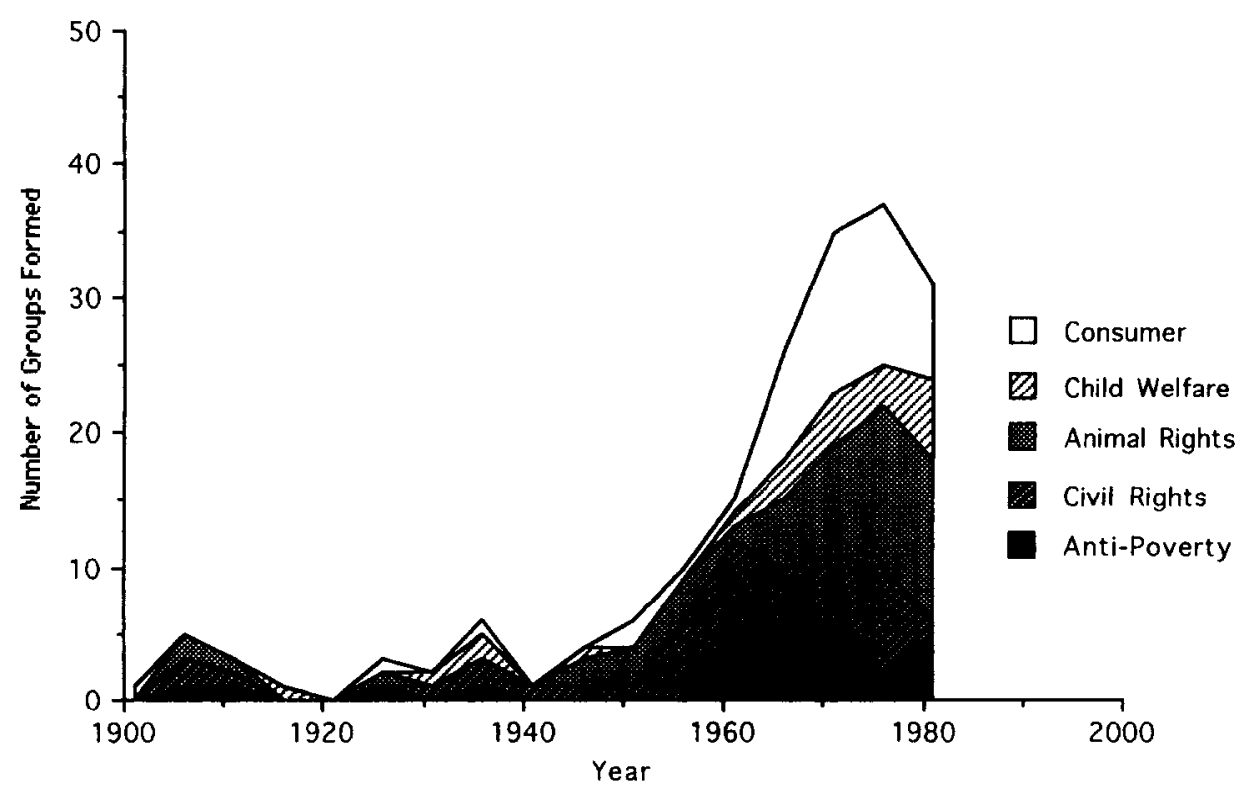

Source: The Encyclopedia of Associations

Figure 1. Patterns of Group Formation Across Sectors, 1900-1985 


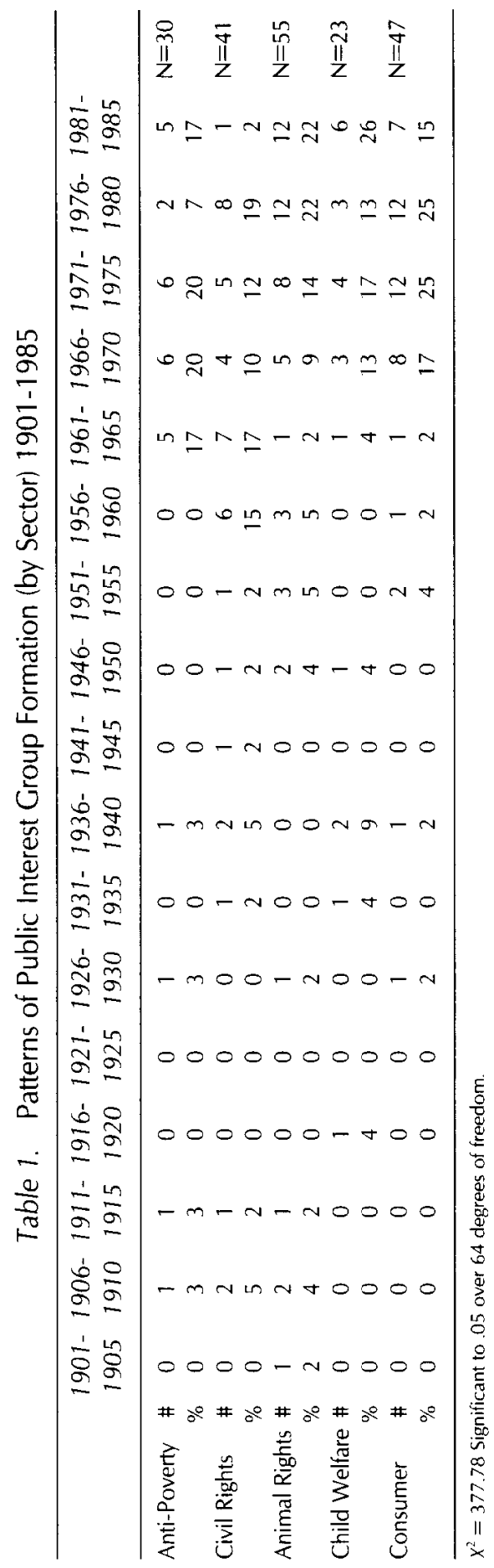


in new group formation first between 1900 and 1920, then between 1935 and 1940 , and then increasing at a rapid pace from 1966 to 1975.

These periods coincide with broader shifts in national attention, government policy, and political economy. All sectors spawned new organizations with increasing frequency from the New Deal forward, most dramatically during the middle 1960 s through the mid-80s. Indeed, fully 68 percent (133 groups) of the groups found in 1989 formed after the advent of the Great Society in 1965. In regard to questions of social justice, for example, sectoral expansion accompanied the settlement house movement, the New Deal, and the Great Society programs. By far the greatest period of expansion among these public interest sectors occurred between 1966 and 1975, coinciding with expansions of federal initiatives. Expanded federal and private support resulted in a rapidly increasing number of public interest group claimants. ${ }^{51}$

The increasingly turbulent picture characterizing the period between 1975 and 1985 (roughly the period including the Carter presidency and first Reagan term) also indicates the effectiveness with which the Reagan administration attacked the network of challenging and dissident public interest groups reliant on some combination of federal and foundation support, ${ }^{52}$ as shown by the rapid decline in rates of group formation within the anti-poverty, child welfare and civil rights sectors. Their subsequent resurgence later in the decade, in response to perceived hostility from the Reagan administration to domestic social spending, confirms the importance of political context to group formation.

Group formation also varied from sector to sector. A notable increase in activity in the civil rights sector accompanied the developing civil rights movement and continued through the subsequent government response, the War on Poverty. Animal rights groups, which emerged periodically throughout the century, surged dramatically during the Carter and Reagan presidencies, when groups concerned with social justice were unable to find similar success. In short, the patterns of public interest group formation suggest that contextual factors affect group development. First, political alignment and patterns of interest representation affect the general pattern of group formation as a strategy for influence. Second, shifts in the political context make certain issue areas more attractive to funders and activists at certain times. Taken together, this means we need to look at the political context in order to understand both strategies of influence and types of interest group claims.

\section{POLICY INFLUENCE}

As political opportunity for a sector declines, groups increasingly seek to wean themselves from dependence on a broader social movement, leading to a pattern of sporadic public interest in a variety of issues. Downs contends that the public's attention span for new issucs is limited, and a protest constituency simply loses interest or shifts its concerns elsewhere as people realize the intractability of major social problems. ${ }^{53}$ In this view, social protest is little more than a sideshow. As a result, groups that define themselves primarily by an issue orientation necessarily lose ground and access with time. The substantial costs of sustaining extrainstitutional mobilization eventually grow so large that entrepreneurs seek 
accommodation with the state and abandon extra-institutional activity, or lose the capacity to mobilize sufficient support to continue operations. Organizations thus seek to devise moderate goals and strategies that allow them to routinize and institutionalize their activity, abandoning their own grassroots.

Institutionalized organizations find their concerns moderated and their range of activity limited. The political ramifications of this institutionalization remain a matter of contention. ${ }^{54}$ Some scholars argue that institutionalization may provide a platform for launching broader and more effective challenges to state policy. ${ }^{55}$ Others contend that institutionalization may allow groups to be more effective, but only in pursuit of substantially narrower and incremental goals. ${ }^{56}$ Still others contend that institutionalized groups invariably develop a vested interest in protecting both their own survival and the routinized politics in which they can participate. ${ }^{57}$ Activists and scholars alike are left with a confusing message about interest group and social movement activity, and little clear direction about routes for meaningful change. The policy effects of various strategies of influence is an important area for further research.

\section{SECTORAL MOBILIZATION AND PUBLIC POLICY: A CYCLE OF GROWTH AND DECLINE}

In the sections above, we've reviewed the relevant issues connected with sectoral mobilization and decline, suggesting a relationship between external and internal factors on group politics. While the tactical decisions groups make are surely important to their prospects for survival or influence, more critical is the broader policy climate within which groups operate. Sectors expand in response to a nascent social problem, groups seek institutional access and stability, perhaps generating policy response, then seek to survive when the wave of public attention has passed. We present below a schematic six stage model of a cycle of public interest group expansion and contraction:

1. Recognition of a Social Problem: A disturbance to the status quo arouses public concern and/or dissent. This may result from policy reform, swings in political alignment, or new policy problems.

2. Extra-Institutional mobilization takes place at one or several levels, ranging from expert disaffection reflected in critical journal articles to street protest.

3. Media Recognition of both the policy problem and social protest defines social and political problems, frames potential solutions, and identifies relevant actors.

4. Resource Mobilization may include funding from private, foundation, corporate, and government sources, as well as increased member interest. It is accompanied by relaxed barriers to government access for public interest groups associated with the recognized issue.

5. Niche Building activity ensues as groups try to solidify their positions, differentiate among themselves, and stabilize the demand for their activity, ensuring organizational survival. 
6. Resource Contraction follows from a number of outcomes including policy success (satisfying concerned supporters), unambigous defeat through repression, or shifting public interests. As available resources contract, there is a "shake-out" within the sector, and groups disappear or retrench.

\section{CONCLUSION}

In this article, we've shown that political context plays a critical role in the emergence and development of public interest groups. We have argued that sectoral rather than individual group analysis promises the best means of assessing the influence of organized groups on the policy process, specifically because it allows analysts to establish a context in which groups' strategic and tactical decisions take place. We've presented data on interest group formation which strongly suggests we look not to the issue entrepeneur, but to the political context in order to understand group formation and activity.

We've suggested a six stage framework, which follows groups from incipient interests to entrenched organizations, to organize subsequent research. Sectoral analysis, in the context of awareness of cyclic patterns of mobilization and institutionalization, should help us understand the circumstances under which groups emerge, the relation of groups to broader social movements, and the ultimate influence of groups on policy. Sectoral analysis, along with the six stage framework we outline, demands further research that explicitly seeks to connect interest group activity to both social movements and the policy process. These are important matters, both theoretically and politically.

One of the ongoing problems with democratic systems concerns who has a voice in decision-making. This article has suggested that while public interest groups may provide an important type of representation otherwise absent from decision making forums, public interest groups gain and lose influence in a highly constrained context. The political and policy impact of a cycle of dissident protest is an ultimate test of democracy in the United States. To the extent broad public concerns win serious attention within political institutions and elicit meaningful policy response, the pluralist interpretation of American democracy holds. If, however, cycles of protest end with symbolic incorporation and rhetorical concessions without real procedural inclusion or policy reform, interest group liberalism remains a diversion from democracy rather than its embodiment.

Acknowledgments: We thank Rick Tilman and Andrew McFarland for their thoughtful comments on earlier drafts of this article, and Laura Williamson for clerical help.

\section{NOTES}

1. David Truman, The Governmental Process (New York: Knopf, 1951), p. 38.

2. Robert $\Lambda$. Dahl, $A$ Preface to Democratic Theory (Chicago: University of Chicago, 1956).

3. Peter Bacharach and Morton S. Baratz, Power and Poverty (New York: Oxford University, 1970); E.E Schattschneider, The Semi-Sovereign People (New York: Holt, Reinhart \& Winston, 1960). 
4. John Gaventa, Power and Powerlessness: Rebellion and Quiescence in an Appalachian Valley (Champaign-Urbana: University of Illinois Press, 1981).

5. See especially, Theodore J. Lowi, The End of Liberalism (New York: Norton, 1979).

6. Mancur Olson, The Logic of Collective Action (Cambridge: Harvard University Press, 1965); Terry M. Moe, The Organization of Interests (Chicago: University of Chicago Press, 1980); Lawrence S. Rothenberg, "Organizational Maintenance and the Retention Decision in Groups," American Political Science Review, 82:1129-1152.

7. Robert H. Salisbury, "An Exchange Theory of Interest Groups," Midwest Journal of Political Science, 13 (1969): 1-32.

8. John Mark Hansen, "The Political Economy of Interest Group Membership," American Political Science Review, 79 (March 1985)1: 79-96; David Knoke, "Incentives in Collective Action Organizations." Paper presented at the annual meeting of the American Sociological Association Meetings, Chicago IL, August 1987; Robert H. Salisbury, John P. Heinz, Edward O. Laumann, and Robert L. Nelson, "Who Works with Whom? Interest Group Alliances and Opposition," American Political Science Review, 81 (1984): 1217-1234.

9. Neil Smelser, Theory of Collective Behavior (New York: Free Press, 1963); for a range of related theories, see Eric Hoffer, The True Believer (New York: Harper \& Row, 1951); William Kornhauser, The Politics of Mass Society (Glencoe, IL: Free Press, 1959); Ted Robert Gurr, Why Men Rebel (Princeton: Princeton University Press, 1970).

10. See, Michael Lipsky, Protest in City Politics (Chicago: Rand McNally, 1970); Anthony Oberschall, Social Conflict and Social Movements (Englewood Cliffs, NJ: PrenticeHall, 1973); John D. McCarthy and Mayer N. Zald, "Resourse Mobilization and Social Movements: A Partial Theory," American .Journal of Sociology (1977) 82: 1212-1241; John D. McCarthy and Mayer N. Zald, The Trend of Social Movements in America: Professionalization and Resource Mobilization (Morristown, NJ: General Learning Press, 1973).

11. E.g., William A. Gamson, The Strategy of Social Protest 2nd ed. (Belmont, CA: Wadsworth, 1990); Doug McAdam, Political Process and the Development of Black Insurgency (Chicago: University of Chicago Press, 1982); Sidney Tarrow, Democracy and Disorder: Protest and Politics in Itlay, 1965-1975 (New York: Oxford University Press, 1989a); Tarrow, Struggle, Politics and Reform: Collective Action, Social Movements and Cycles of Protest (Ithaca, NY: Cornell University Center for International Studies, 1989b); Charles Tilly, From Mobilization to Revolution (Reading, MA: Addison-Wesley, 1978).

12. Jeffrey Berry, Lobbying for the People (Princeton, NJ: Princeton University, 1977); Jane Mansbridge, Beyond Self-Interest (Chicago: University of Chicago Press, 1990).

13. Bruce Fireman and William A. Gamson, "Utilitarian Logic in the Resource Mobilization Perspective," in The Dynamics of Social Movements, edited by M.N. Zald and J. McCarthy (Cambridge, MA: Winthrop, 1979), pp. 8-44; Knoke, op. cit.

14. Andrew S. McFarland, Common Cause: Lobbying in the Public Interest (Chatham, NJ: Chatham House, 1984); Rochelle L. Stanfield, "Defending the Left May Remain Just Another Fond Dream of Conservatives," National Journal (September 1, 1981): 1374-1378; Kay Lehman Schlozman and John T. Tierney, Organized Interests and American Democracy (New York: Harper \& Row, 1986); David S. Meyer, $A$ Winter of Discontent: The Nuclear Freeze and American Politics (New York: Praeger, 1990).

15. Mark Granovetter, "Threshold Models of Collective Behavior" American Journal of Sociology, 83 (1978) 6:1420-1443; Paul Johnson, "Foresight and Myopia in Interest Group Membership," Journal of Politics, 49 (1987): 678-703; Suzanne Staggenborg, 
"The Consequences of Professionalization and Formalization in the Pro-Choice Movement," American Sociological Review, 53 (1988): 585-606.

16. Peter K. Eisinger, "Conditions of Protest Behavior in American Cities," American Political Science Review, 67 (1973): 11-28.

17. Tilly, op. cit., pp. 98-100.

18. Herbert P. Kitschelt, "Political Opportunity Structures and Political Protest: AntiNuclear Movements in Four Democracies," British Journal of Political Science, 16 (January 1986):57-85.

19. William A. Gamson and David S. Meyer, "Framing Political Opportunity," paper presented at the annual meeting of American Sociological Association, Pittsburgh, PA, 1992.

20. McAdam, op. cit, p. 97.

21. Ibid., p. 170; also see J. Craig Jenkins and Craig M. Eckert, "Channeling Black Insurgency: Elite Patronage and Professional Social Movement Organization in the Development of the Black Movement," American Sociological Review, 51 (December 1986): 812-829.

22. Jo Freeman, The Politics of Women's Liberation (New York: David McKay, 1975); J. Craig Jenkins and Charles Perrow, "Insurgency of the Powerless: Farm Workers Movements (1946-1972)," American Sociological Review, 42 (April 1977): 249-268; Meyer, op. cit; Lipsky, op. cit; Frances Fox Piven and Richard A. Cloward, Poor People's Movements (New York: Vintage, 1979).

23. Peter Gourevitch, Politics in Hard Times (Ithaca: Cornell University Press, 1986), p. 34.

24. Ibid.; also see Walter Dean Burnham, The Current Crisis in American Politics (New York: Oxford University, 1982); Thomas Byrne Edsall, The New Politics of Inequality (New York: Norton, 1984).

25. Meyer, op. cit., p. 8.

26. John Kingdon, Agendas, Alternatives, and Public Policies (Boston: Little, Brown, 1984); Mayer N. Zald and John D. McCarthy, "Social Movement Industries: Conflict and Competition Among SMO's," in Social Movements in an Organizational Society, edited by Idem (New Brunswick: Transaction, 1987), pp. 161-180.

27. Theodore J. Lowi, The Politics of Disorder (New York: Basic, 1971).

28. E.g., Milton S. Katz, Ban the Bomb: A History of SANE, 1957-1985 (Westport, CT: Greenwood, 1986); McFarland, op. cit.

29. Jeffrey Berry, The Interest Group Society (Boston: Little, Brown, 1984); Lowi, 1979, op. cit; Schattschneider, op. cit; Kay Lehman Schlozman, "What Accent the Heavenly Chorus? Political Equality and the American Pressure System," Journal of Politics, 46 (1984): 1006-1032.

30. Paul Burstein, "Policy Domains: Organization, Culture, and Policy Outcomes," Annual Review of Sociology, 17 (1991):327-350; Hugh Heclo, "Issue Networks and the Executive Establishment," in The New American Political System, edited by Anthony King (Washington: American Enterprise Institute, 1978), pp. 87-124.

31. Zald and McCarthy, op. cit, use the term "sector" more inclusively, too much so we think, to include all groups pursuing a broad variety of strategies for influence, suggesting the existence of an interest group sector, a social movement sector, and so forth. They label groups that pursue similar policy agendas "industries." The terminology implies an overly narrow definition of politics as "product" supporters choose (and consume?). Our sectoral definition recognizes groups' dual roles: to satisfy members and to affect policy change. 
32. James Q. Wilson, Political Organizations (New York: Basic Books, 1973); Zald and McCarthy, op. cit.

33. Berry, 1977, op. cit.

34. While not nearly as plentiful as business, trade, or professional associations, the number of public interest groups has expanded rapidly since the 1960s. By the middle 1980s, public interest groups comprised approximately 20 percent of groups active in the Washington pressure mix. See Douglas R. Imig, "Resource Mobilization Strategic Action and Poverty Advocacy," Western Political Quarterly, 45 (June 1992):501-502; Salisbury, op. cit; Schlozman, op. cit; Jack L. Walker, "The Origin and Maintenance of Interest Groups in America," American Political Science Review, 72 (June 1983):390-406.

35. E.g., Larry Sabato, PAC Power (New York: Norton, 1984); Kay Lehman Schlozman and John T. Tierney, Organized Interests and American Democracy (New York: Harpcr and Row, 1986).

36. Salisbury et al., op. cit., emphasize the importance of comparing groups within and across policy domains: "It was our firm belief that unless we linked our analysis ... to the substantive policy concerns of the groups involved we would have ... interest group activity without interests (p. 219)."

37. Rosenthal et. al. show that women's rights activists in the nineteenth century worked on a variety of issues over time, choosing those groups and issues that offered the greatest access to the political arena at any given time. See "Social Movements and Network Analysis: A Case of Nineteeth-Century Women's Reforms in New York State," American Journal of Sociology, 90 (1985): 1022-1054.

38. James Q. Wilson, Political Organizations (New York: Basic, 1973), pp. 262-263.

39. McCarthy and Zald, 1977, op. cit., pp. 1224-1225.

40. McFarland, op. cit.; Rothenberg, op. cit.

41. Gamson and Meyer, op. cit.

42. McCarthy and Zald, 1977, op. cit., p. 1234.

43. Staggenborg, op. cit.

44. Meyer, op. cit., pp. 142-145.

45. Wilson, op. cit., p. 31.

46. Piven and Cloward, op cit., p. xxi and passim.

47. Michael W. McCann, Taking Reform Seriously: Perspectives on Public Interest Liberalism (Ithaca: Cornell University, 1986).

48. Lipsky, op. cit., p. 170; Todd Gitlin, The Whole World is Watching (Berkeley: University of California, Press, 1980), p. 182.

49. Lowi, 1971, op. cit.

50. National organization directories such as The Encyclopedia of Associations and Washington Representatives provide founding dates and organizational missions for the broad spectrum of both extant and extinct political interest groups, and are therefore a critical data source. For examples of their use, see Debra C. Minkoff, "Bending With the Wind: Organizational Change in American Women's and Minority Organizations, 1955-1985," paper presented at the annual meeting of the American Sociological Association, Pittsburgh, PA, 1992; Salisbury et al., op. cit.; Schlozman, op. cit.; Walker, op. cit.

51. Helco, op. cit.; Walker, op. cit.

52. Mark Peterson and Jack Walker, "Interest Group Responses to Partisan Change." in Interest Group Politics (2nd edition), edited by Allan Cigler and Burdett Loomis (Washington DC, 1986):CQ, 162-182. 
53. Anthony Downs, "Up and Down with Ecology: The Issue Attention Cycle," The Public Interest, 28 (Summer 1972): 38-50.

54. For an overview, see David S. Meyer, "Institutionalizing Dissent: The United States Structure of Political Opportunity and the End of the Nuclear Freeze Movement," Sociological Forum, 8 (June 1993): 157-179.

55. E.g., Joyce Marie Mushaben, "Reflcctions on the Institutionalization of Protest: The West German Peace Movement," Alternatives, IX (Spring 1984): 519-539; Rufus P. Browning, Dale Marshall, and David H. Tabb, Protest is Not Enough (Berkeley: University of California, 1984).

56. E.g. Gamson, op. cit.; Tarrow, 1989a, op. cit.

57. E.g., Lowi, 1971, op. cit.; Stephen R. Smith and Michael Lipsky The Community of Welfare (Cambridge: Harvard University Press, 1993); Tilly, op. cit., p. 151. 